\title{
Gender and Development: Mainstreaming the Female Gender in Trade Union Leadership Structure in Nigeria
}

\author{
Ahule, Benjamin Gowon (Ph.D.) \\ Department of Sociology Benue State University, Makurdi.
}

\begin{abstract}
This paper delves into gender and development. Particularly, it focuses on the need to mainstream the female gender in the leadership structure of trade unions. The aims is to emphasise the fact that the female gender is an active part in the development process. Thus their continued neglect will mean delay in the development process and any society that integrate the female gender will definitely add value to its development efforts. The paper utilises the functionalist theoretical framework, which emphasises the functionality of the female gender in ensuring the stability of trade unions. Thus the exclusion of women in trade union structure is not only a denial of the rights of female gender but also the benefits that trade unions could derive from their contributions. The paper also emphasized that over few women have been involved in the leadership structure of trade unions not only in Africa but in Europe as well. The paper also identifies problems militating against an expanded women participation in trade unions. They include the fact that: Women do not understand or appreciate how unions can benefit them: Women fear reprisals from employers (including losing their jobs) for joining unions; Women do not have time to join or participate in union activities because of conflicting family responsibilities, and childcare facilities are lacking or too expensive among others. The paper finally calls on trade unions to evolve strategies that will consistently encourage equal representation of both men and women in leadership positions in order to contribute to the development of not only the organization they serve but society at large.
\end{abstract}

Submitted Date 04 Apr 2013

Accepted Date: 01 May 2013

\section{Introduction}

Interest in gender studies has grown tremendously over the years. The concern has not been to challenge socially constructed relations between men and women alone but also to analyse it as a development issue. Societies the world over have been patriarchal as the perceptions about women have largely been the same. In most societies, there is male domination and female subordination in many spheres of life. The tasks, roles, functions attributed to men are valued higher than those of women. Equally, the male norm is taken as the norm for the society as a whole, which is reflected in policies and structures.

It is well known that inheritance laws and traditions, marriage arrangements, banking systems and social patterns that reinforce women's dependence on fathers, husbands and sons all contribute both to their unfavourable access to resources and their lack of power to change things (Folorunsho, 2009). This gender endangered atmosphere is today being understood in countries that had hitherto been in the dark. Thus, it is becoming clearer in many parts of the world that women make key contributions in areas of development (Hannan, 2003).

It could be argued that the premise for this monumental shift in attitude and position is probably due to the realization that developmental practices should allow for unhindered women's participation in all relevant and available economic, as well as socio-political programmes; give women full opportunities to explore and develop their potentials to the optimum and acknowledge their efforts (Folorunsho, 2009). Indeed, societies that have given women more access to development resources have no regrets and can vouch for the tangibility of their contributions to the upliftment of such societies.

\section{Definitions of "gender mainstreaming" and "Trade unions"}

This concept of gender mainstreaming has attracted the attention of people in diverse areas of human endeavour including academics, researchers, non-governmental organizations, and diverse groups of persons concerned about women issues. Their definition of the concept has often based on their differing backgrounds and ideological orientations.

An authoritative definition of gender mainstreaming is presented thus:

"Mainstreaming ... is the process of assessing the implications for women and men of any planned action, including legislation, policies or programmes, in all areas and at all levels. It is a strategy for making 
women's as well as men's concerns and experiences an integral dimension of the design, implementation, monitoring and evaluation of policies and programmes in all political, economic and societal spheres so that women and men benefit equally and inequality is not perpetuated. The ultimate goal is to achieve gender equality.”(Hannan, 2003:15)

From the above definition, gender mainstreaming involves bringing relevant gender perspectives to the centre of attention in substantive work - both in more socially-oriented sectors or issues such as health, education, agriculture where the gender perspectives are relatively well understood and accepted, and in sectors and issues where the linkages to gender equality are less well recognized, such as in trade unions among others. Gender mainstreaming further involves ensuring that these gender perspectives, once identified, are incorporated into the many different types of activities through which objectives of (Hannan, 2003) unions are achieved. This requires explicit, systematic attention to gender perspectives (Hannan, 2003) in all union affairs.

The concept of trade union has also attracted variety of definitions from scholars. All these definitions however center on workers and their welfare. For instance, Fajana in Nchuchuwe and Ajalor (2008) defines trade union as "an association of wage or salary earners formed with the object of safe guarding and improving the wage and employment conditions of its members and to raise members' social status and standards of living in the community. Sidney and Beatrice Webb in Nchuchuwe and Ajalor (2008) also defined Trade Union as a continuous association of wage earners for the purpose of maintaining or improving the condition of their working lives.

Furthermore, the Nigerian Labour law Section 1 of Sub section 1 Trade Union Act No 31 of 1973 buttresses this point further and defines Trade Unions as 'any combination of workers or employers whether temporary or permanent, the purpose of which is to regulate the terms and conditions of employment of workers whether the combination in question would not, apart from this act, be an unlawful combination by reason of its purpose or any of its purpose be it in restraint of trade and whether its purpose do not include provision of benefits for its members.

\section{Theoretical framework}

This paper adopts structural functionalism theory. The theory is built around key concepts such as consensus, order, agreement and stability etc. Utilizing organism analogy, the theory posits that society is made up of structural components and each of them serves a useful function. The functionality of these parts ultimately leads to the stability, unity and social order of society. The implication of this Parsonian theory in the analysis of gender mainstreaming in trade unions is to emphasise the functionality of the female gender in ensuring the stability of trade unions. Thus the exclusion of women in the trade union structure is not only a denial of the rights of female gender but also the benefits that trade unions could derive from their contributions. This theory is however often criticized for being conservatively opposed to change. But while change in terms of gender mainstreaming is sought in trade unions in the context of this paper, this type of change is not a radical one but one that keeps trade unions within the existing conservative order.

\section{Misconceptions about gender mainstreaming}

Two important and pervasive misconceptions of gender mainstreaming have been clarified by Hannan (2003). Firstly, gender mainstreaming is not about gender balance within organizations, although this is an important element of overall efforts to promote gender equality. Every organization must have a dual strategy efforts to promote gender equality within the organization itself, combined with efforts to promote attention to gender perspectives within the work of the organization. Gender mainstreaming is focused on the work programmes of organizations - the goals, strategies, resource allocations and planning and implementation processes.

Secondly, separate specially targeted activities for women are not gender mainstreaming activities but a necessary complement to gender mainstreaming. As the term "mainstreaming" implies, gender mainstreaming means bringing gender perspectives into regular "mainstream" activities - research, analyses, policies, programmes, etc. - which are not specifically targeted to women. Gender mainstreaming is the strategy utilized in programmes where the principal objectives are related to other development goals than gender equality - such as improvements in health status, greater agricultural productivity, improved transport, more efficient energy consumption. Gender mainstreaming involves linking the goal of gender equality to these other development goals, in the context of "mainstream" development policies and programmes.

Much more importantly, gender mainstreaming is an organisational strategy to achieve and maintain gender equality and women's empowerment. Achieving equality between men and women is not a 'woman's' concern, but is fundamental to the aims of all trade unionists. Dynamic measures that target women are required in order to redress existing discrimination and change attitudes and conditions in the unions and by the unions. There is also a need for measures to both increase awareness among women and to enable them to reconcile 
work with their personal and family life, while also allowing men to spend time with their families and share family responsibilities (Hannan, 2003).

\section{Overview of Women and trade unionism}

The interest in the participation of women in trade unionism is a world-wide concern. Several studies have been carried out in Europe and elsewhere on the participation of women in trade unionism. One of such is a study of the existing Literature and Survey carried out among organisations affiliated to the European Trade Union Condeferation in (2002) among others. On the whole, the low level of women participation in decision making structure of trade unions has remained at the centre of their discussions. In a worldwide survey by the International Labour Organisation (ILO) in 1999, there was no proportional representation for women in trade union management. They held less than a third of senior decision making posts in over $60 \%$ of the trade unions studied. Similarly, the "Second Sex" of European Trade Unionism survey carried out among the various organizations affiliated to the European Trade Union Confederation demonstrated in 1999 - that despite an increase in the number of women in decision-making bodies between 1993 and 1999 - there was still persistence in under-representation by women in trade union decision-making (Garcia, 2002).

Furthermore, in Africa too, "women continue to be fewer in numbers in unions, although there are indications that the female membership of executive committees has been rising as unions have started stating in their constitutions and strategy documents their intention to strengthen the gender balance and to promote gender equality. One of such countries is The Gambia (Hannan, 2003). Despite this growing trend however, the expectation that women will obtain maximum participation is yet to be attained. According to Hannan (2003), "efforts to recruit women into unions have at times proved difficult ..."

In Europe, the situation is different today. According to Trebilcock in Garcia (2002) trade union organisations have made use of various strategies to try to tackle the issue of the chronic under-representation of women in decision-making positions. This positive action includes the implementation of Conferences on women, the creation of Women's Committees, Equality Commissions, Women's Departments and appointing persons responsible for equality, the establishment of quotas, reserved seats, guarantee of proportional representation, the existence of new approaches in conducting trade union affairs and educating women in exercising responsibilities. However, when compared with their counterparts from other nations, women in Nigeria do not take active part in the leadership of labour unions. If at all, women participation is minimal.

While a few women have been able to achieve this feat in unions with large number of females such as the Nigeria Association of nurses and Midwives, there are few women in leadership positions of other unions. However, several studies on women in black Africa and indeed Nigeria have revealed that although there have been increased participation of women in wage labour in the past three decades; they have not significantly improved their involvement in union affairs, especially in leadership roles. A larger proportion display total indifference to trade union matters. Thus while women traders have acted collectively in the past to protect their interest, the same can hardly be said of the female wage workers (Nwobodo, 2009) today.

\section{Barriers against women in Trade Union structure in Nigeria.}

Different scholars have identified barriers preventing women from being integrated into trade union structures. One of the reasons identified specifically about Nigeria is that the level of discrimination against women is still very high. The 1999 Constitution of the Federal Republic of Nigeria does not give a comprehensive definition of the concept of discrimination against women, as it only gives a general note against all forms of discrimination including discrimination on the basis of sex. Other laws that are specifically made on discrimination against women exist only in five states and are rarely enforced. Some provisions of the Constitution outrightly discriminate against women. For instance, the Constitution provides that Women who marry non-Nigerians cannot confer Nigerian citizenship on their husbands by virtue of the marital union, while Nigerian men who marry non-Nigerians automatically have Nigerian citizenship conferred on their wife on the basis of marriage (Nigeria CEDAW NGO Coalition Shadow Report, 2008).

The worldwide study conducted by ILO in 1999 identified the following main factors preventing women from joining trade unions: women's lack of knowledge about the benefits of trade union membership, fear of reprisals by employers and lack of time due to family responsibilities. Citing the works of Crozier (1965) and Legendre (1987) the numerical under-representation of women in trade unions was an extension of the attitude of staying in the background at work and also conveyed some sort of lack of interest in trade unions.

The International Labour Organization in Nwobodo (2009) and Folorunsho (ND) identify a number of constraints militating against women's integration in trade union structure world wide. These include:

$>$ Women do not understand or appreciate how unions can benefit them;

$>$ Women fear reprisals from employers (including losing their jobs) for joining unions;

$>$ Women do not have time to join or participate in union activities because of conflicting family responsibilities, and childcare facilities are lacking or too expensive. 
$>$ Women often lack the confidence to join unions or to aspire to leadership positions;

$>$ Religious and cultural norms and traditions prevent women from joining;

$>$ Women face oppositions from their spouses or families; when they decide to be active unionists

$>$ The male-dominated culture or activities of the union or hostile reactions from male members discourage women from joining;

$>$ Stereotyped ideas persist about womens' abilities, preferences and roles;

$>$ Unions are not sensitive to the needs of women workers;

$>$ Membership dues are a problem especially for poor working women;

$>$ Women are more likely than men to be in atypical forms of work or in the informal sector where they are difficult to reach and organize.

$>$ There may be legal constraints to some groups of women workers joining unions;

$>$ Entrenched union rules and structures are not conducive to women's participation and advancement to leadership positions;

$>$ Informal procedures in the unions for nominations or appointments rely on established male networks.

$>$ Other identified barriers to women participation union activities are

$>$ Religion - some religious affiliations have beliefs that prevent women from working and thus reduce the probability of joining and participating in trade unionism. Also while in employment, some religions affiliations forbids women from interacting with males who are not their husbands are family relations.

$>$ Male union environment - the prevalent notion is that working in a union is a 24r hour a day job. While men occupying the existing union structures find it easy to perpetuate some prejudices, values and stereotypes unfavourable to women.

$>$ Limited experience and training - some unions have evolved electoral guidelines, which stress union experience and training, prerequisites that women lack

$>$ Male union environment - the prevalent notion is that working in a union is a 24r hour a day job. While men occupying the existing union structures find it easy to perpetuate some prejudices, values and stereotypes unfavourable to women.

$>$ Limited experience and training - some unions have evolved electoral guidelines, which stress union experience and training, prerequisites that women lack

$>$ Long and unusual work hours - responsibilities of trade unionists, either elected or appointed involve long, sudden unusual hours and traveling, which female workers may not be able to cope with.

$>$ Marital status, a married woman may find it harder to participate in trade union activities than a single or divorced woman.

Despite these restrictions against women, they have been adjudged worthy of leadership. Nwobodo (2009) further identifies the Caliper study findings and summarized them into four specific statements about women's leadership qualities. It means that women, when given the opportunity will perform excellently given the following; that: 1 . Women leaders are more persuasive than their male counterparts. 2 . When feeling the sting of rejection, women leaders learn from adversity and carry on with an "I'll show you" attitude. 3. Women leaders demonstrate an inclusive, team-building leadership style of problem solving and decision making. 4. Women leaders are more likely to ignore rules and take risks. According to him, these inherent qualities of women make them good leaders and can even excel in their assigned responsibilities.

Nwobodo (2009) while further citing Wachs book Why the Best Man for the Job is a Woman: The Unique Female Qualities of Leadership, examines the careers of fourteen top female executives to establish what makes them so successful. She discovers among them, Meg Whitman, President and CEO of eBay to have the following qualities: a willingness to reinvent the rules; an ability to sell their visions; the determination to turn challenges into opportunities; and a focus on 'high touch' in a high tech business world. In fact the fame that Margaret Thatcher, Indira Ghandi, and Benazir Bhutto brought to leadership in their various countries attests to this. In Nigeria, Grace Alele Williams and Dora Akunyili, to mention a few, have left impressive memories of women's leadership integrity.

\section{Mainstreaming women in trade union structure}

Nigeria is known to be signatory to many international conventions and laws aimed at promoting gender mainstreaming into national societies. For instance, Nigeria is signatory to the Convention for the Elimination of All Forms of Discrimination Against Women (CEDAW). She has also evolved national gender policies such as The Federal and States Ministries of Women Affairs and Social Development; National Centre for Women Development; Gender Desks established in some of the Ministries and agencies as measures taken to enhance the full advancement of women. The closest provision for economic, social and cultural rights is found in Chapter 2 of the Constitution and it is titled Fundamental Objectives and Directive Principles of State Policy. This means that Nigeria ought to adhere to these conventions. Consequently trade unions should also be seen operating in an environment that is receptive to mainstreaming than it is hitherto the case. The International 
Labour Organisation has maintained that unions are still not women friendly and the inclusion of gender perspectives in all trade union policies and programmes is far from being achieved.

Going by the resolutions of the $3^{\text {rd }}$ NLC gender conference held at Hamdala hotel, Kaduna on the $10^{\text {th }}$ and $11^{\text {th }}$ March 2008, trade unions have the clear option of mainstreaming women into their structures. The conference specifically gave its affiliate unions up to the end of 2010 to fully implement the NLC Gender Equity Policy. A follow up advocacy and assessment of level of implementation was to be made, the report of which was to be made at the NLC National Delegates Conference in 2011. The same conference also resolved that affiliate unions should implement the 30\% women representation in leadership positions at all levels including all activities. Such unions that fail to do so should be prevented from participating in NLC conferences or activities.

It is a point of emphasis that the exclusion of women in the mainstream of trade unions is not only a denial of their right to associate but also the contribution they can make to the development of not only the organization they serve but society at large. As already indicated above, women have the requisite competence to serve, some times even better as has earlier been pointed out. Women serve better due to certain reasons as Briskin notes in Nwobodo (2009): Briskin suggests that two factors significantly contribute to the making of women union leaders: (1) the discrimination they experience in the workplace, the community, at home and in the union, and, (2) the practice of forming both formal and informal women constituencies within unions in response to that discrimination. Discrimination therefore contributes to women's leadership development.

On the strength of women's leadership competence, the International Labour Organisation (ILO) (1996) called on unions to evolve strategies that will consistently encourage equal representation of both men and women in leadership positions because of the following reasons:

i. Women account for an increasing proportion of the workforce;

ii. To be credible and strong, unions must address the priority concerns of its current and potential members; and women concerns are numerous.

iii. To be credible to women, unions must demonstrate that gender equality is an integral part of their own policies and structures;

iv. Growing number of women workers are standing up for their rights and seeking support for their rights;

v. Women members are positively changing the way unions work and improving the image and influence of unions;

vi. The promotion of gender equality helps unions strengthen and reaffirm their key role as agents of social change;

vii. The promotion of gender equality provides common grounds for unions to forge alliances with other social actors

Furthermore, trade unions need to take practical steps in mainstreaming women into its leadership structure. Four key factors have been identified as crucial. These are: leadership - people at the top must lead the way to make gender mainstreaming work. It is clearly the responsibility of officials - ensure everyone knows what to do, make a short checklist and give this to all those involved, building expertise and training discussion, practical help, understanding the benefits to the whole union from mainstreaming, challenging negative attitudes, monitoring and reviewing your plan - membership involvement in collecting evidence of union performance, reviewing and making changes to the plan where necessary (ITUC, 2008). See attached checklist for further information on practical steps to mainstreaming.

\section{Conclusion}

To ensure that women are mainstreamed into trade union leadership structure requires the cooperation of their male counterparts who have over centuries dominated the entire society and its institution. Men need to understand and appreciate the lack of opportunities that confront women due to societal definitions of gender roles. As can be seen most activities women engage in should not be their exclusive preserve but simply because they have been stereotyped. When this is appreciated, the course to gender mainstreaming will have been charted.

\section{References}

[1]. Ahmed, S. \& Rafi, M. (2003) Poverty Alleviation And Empowerment Of Women: The Brac Experience in Putting Gender Mainstreaming Into Practice Economic And Social Commission For Asia And The Pacific

[2]. Folorunsho, O. (2009) The Role of Women in Trade Unions and Nation Building. Available on www.pengassan.org/......

[3]. Garcia, A. (2002) Women in Trade Unions: Making the Difference. Research on Women and Decision-Making in Trade Union Organisations. Study of the existing Literature and Survey carried out among organisations affiliated to the European Trade Union Condeferation.

[4]. Hannan, C. (2003) "Overview of Gender Maintreaming” in Putting Gender Mainstreaming into Practice. Publication of Economic and Social Commission for Asia And The Pacific

[5]. International Labour Office, (1996); World labour report. Geneva.

[6]. ITUC (2008) Achieving Gender Equality: A Trade Union Manual. Brussels: International Trade Union Confederation. 
[7]. Nchuchuwe, F. \& Ajulor, O. N. (2008) The Roles of Trade Unions and Civil Society in Good Governance: The case of Nigeria from 1999 Till Date.

[8]. Nigeria Labour Congress 3rd National Gender Conference. Held at Hamdala Hotel, Kaduna on the 10th and 11th march 2008. Available at www.nlcng.org/search, detal php id.

[9]. Sosseh, N. T. (2009) "Promoting Gender Equality within Unions Structures and at the Workplace" in Standing Up For Africa Union Solidarity and Quality Journalism Working For Democracy. Nairobi: Federation of African Journalists.

[10]. The Nigeria CEDAW NGO Coalition Shadow Report submitted to the $41^{\text {st }}$ session of the United Nations Committee on the Elimination of All Forms of Discrimination Against Women Holding at the United Nations Plaza New York between June 30 - July 18, 2008. For consideration by the CEADW Committee in its review of the Government of Nigeria's 6th Periodic Country Report (2004-2008) on the implementation of CEDAW in Nigeria

\section{APPENDIX}

\section{Checklist on Mainstreaming}

$>$ The Organisations Policy. Does the organisation have clear policy on all aspects of gender equality including policy to promote the integration of women?

$>$ Use of funds - Is adequate funding provided to carry out all aspects of gender policy?

$>$ Procedures, putting policy into practice. How is the gender policy put into practice, does it really guide all of your activities?

$>$ Understanding needs . Are there significant gaps in your membership? How do you consult members? Do your consultation practices help you to understand the needs of women?

$>$ Decision-making - When making decisions or setting priorities are women well represented? Do you routinely consider the impact of your activities on your women members?

$>$ Monitoring information - Do you collect enough information about women and men to monitor activities by gender? Do you consult monitoring figures when making decisions? Do you regularly use this data to assess the effectiveness of your core activities?

$>$ Visibility - Can a woman.s voice be heard or seen in all your reports, speeches, meetings and publications?

$>$ Breaking down barriers . Do you fully understand the barriers, which deter women from joining, taking part, speaking out or competing for leadership in your union?

$>$ Leadership - Are men in leadership active in promoting change? How do you ensure men develop an understanding of gender issues?

$>$ Women.s structures- Are women.s structures and representatives of women members fully integrated into union decision making structures?

$>$ Targeting. Do you target your activities and services? Are women challenged to get more involved? Do you recognise that positive action may be necessary if you want just results? (ITUC, 2008) 